\title{
Muhasebe Eğitimi Almakta Olan Öğrencilerin Muhasebe Mesleğine Yönelik Tutumlarının Sektörde Çalışma Niyetine Etkisi
}

Oğuzhan ÇARIKÇI*

\section{ÖZET}

Yoğun rekabet ortamında faaliyetlerini sürdüren işletmeler, ayakta kalabilmek ve rekabet avantajı sağlayabilmek için bir takım bilgi ve istatistiklere ihtiyaç duymaktadırlar. Bu bilgilere ulaşmanın yolu, iyi bir muhasebe sistemi ve nitelikli muhasebe çalışanlarına sahip olmaktan geçmektedir. Nitelikli muhasebe elemanları ise üniversitelerin fakülte veya meslek yüksekokullarında yetiştirilmektedir. Bu çalışma önlisans ve lisans düzeylerinde muhasebe eğitimi almakta olan ögrencilerin sektöre yönelik tutumlarını belirlemek ve bu tutumlarının sektörde çalışma niyetlerine etkisini ortaya koymak amacıyla yapılmıştır. 960 öğrenciden elde edilen verilerin analizi sonucunda; ögrencilerin muhasebe alanına yönelik tutumlarına etki eden altı faktör elde edilmiştir. Bu faktörlerden kişi-sektör uyumu ögrencilerin sektörde çalışma niyetini etkileyen en önemli boyut olarak tespit edilmiştir.

Anahtar Kelimeler: Muhasebe Ĕgitimi, Muhasebe Mesleği, Muhasebe Alanında Çalışma Niyeti.

JEL Sinıflandirmasi: M40, M41.

The Effect Of The Attitudes Of Students Receiving Accounting Education Towards The Accounting Profession On Intention To Work In The Sector

\section{ABSTRACT}

Businesses that are continuing their activities in severe competition environment need certain information and statistics to be able to survive and provide competitive advantage. The way to reach this information is to have a good accounting system and qualified accounting employees. Qualified accounting employees are trained in the Faculties or Vocational Schools of universities. This study was carried out in order to determine the attitudes of students receiving accounting education at the associate degree and undergraduate levels towards the sector and to reveal the effect of these attitudes on intention to work in the sector. As a result of the analysis of data obtained from 960 students, six factors affecting students' attitudes towards the accounting field were obtained. Among these factors, the person-sector harmony was determined as the most important dimension affecting the students' intention to work in the sector.

Keywords: Accounting Education, Accounting Profession, Intention to Work in the Accounting Field.

Jel Classification: M40, M41.

\footnotetext{
*Yrd.Doç. Dr. Oğuzhan Çarıkçı, Süleyman Demirel Üniversitesi, Isparta Meslek Yüksekokulu, oguzhancarikci@sdu.edu.tr
} 


\section{GíRİş}

Muhasebe mesleğinin geleceği, yeterli bilgi ve beceriye sahip adayların mesleki eğitimi almalarına ve eğitim sonucunda da temel nitelikleri kazanarak meslek mensupları arasında dâhil olmalarına bağlıdır. Bu nedenle muhasebe eğitimi alan nitelikli adayların muhasebe mesleğine yönelik tutumlarının bilinmesi ve bu tutumların adayların muhasebe alanında çalışma niyetlerine etkilerinin ortaya konulması büyük önem taşımaktadır. Muhasebe eğitimi almakta olan adayların kendi alanlarında çalışmaları için, öncelikle muhasebe mesleğine yönelik tutumlarının belirlenmesi gerekmektedir. Aksi takdirde bu potansiyel nitelikli adayları mesleğe yönlendirecek teşvik edici etkin politikaların geliştirilmesi mümkün olmayacaktır.

İlgili literatürde potansiyel aday konumunda olan muhasebe eğitimi almakta olan öğrencilerin muhasebe programını seçme nedenleri, muhasebe meslek seçimine etki eden faktörlerin belirlenmesi, muhasebe mesleğinin seçilmesinde muhasebe eğitiminin rolü, mesleğe bakışları gibi konuların ele alındığı görülmektedir. Muhasebe eğitimi alan öğrencilerin muhasebe mesleğine yönelik tutumların belirlenmesi ve bu tutumların öğrencilerin muhasebe alanında çalışma niyetlerine etkilerinin ortaya konulmasını ele alan bir çalışmaya yapılan taramada rastlanılmamıştır.

$\mathrm{Bu}$ çalışma ile muhasebe eğitimi almakta olan öğrencilerin muhasebe mesleğine yönelik tutumlarının belirlenmesi ve bu tutumlarının muhasebe alanında çalışma niyetlerine etkilerinin ortaya konulması amaçlanmıştır. Diğer taraftan öğrencilerin muhasebe mesleğine yönelik tutumları ile öğrencilerin cinsiyetleri, öğretim türleri, mezun oldukları lise ve öğrenim gördükleri okul türleri arasındaki farklılıklar incelenmiştir. Çalışma dört bölümden oluşmaktadır. Birinci bölümde muhasebe mesleği ile ilgili teorik özet bilgi verilmiş, ikinci bölümde konuyla ilgili literatür taraması yapılmıştır. Üçüncü bölümde araştırma yöntemi ve bulguları sunularak, son bölümde araştırma sonuçları değerlendirilmiştir.

\section{MUHASEBE MESLEĞİ}

Muhasebe kavramının ortaya çıkışı dolaylı olarak insanlığın ilk yıllarına kadar uzanır ve oldukça eski bir geçmişe sahiptir. Ticaret takas ile başlamış ve bu yolla insanlar mallarını ve hizmetlerini paylaşma imkanı bulmuştur. Böylece insanlar arasında borç-alacak ilişkisi ortaya çıkmıştır. Zaman geçtikçe teknolojik ilerlemelerin de katkısıyla işlem sayısı artmış ve bu durumda beraberinde faaliyetleri kaydetmeyi bir zorunluluk haline getirmiştir. Kaydedilmesi ve takip edilmesi gereken bu bilgiler hem işletmeleri hem de kamuyu ilgilendiren bilgilerden oluşmaktadır. İlgili bilgilerin kaydedilip ihtiyaç duyanlara sunulması işlevini muhasebe sağlamaktadır. Kısacası muhasebe mali nitelik taşıyan işlemlerin tasnif edilip kaydedildiği bir süreç olarak anlaşılmaktadır. Bu süreci biraz daha açacak olursak muhasebe; işletmelerin varlık ya da kaynaklarında değişime yol açan parasal nitelikteki işlemlere ait bilgilerin toplanması, toplanan bu bilgilerin doğru olup olmadığının belirlenmesi, kaydedilmesi, sınıflandırılması, özetlenmesi, elde edilmiş olan sonuçların ise yorumlanarak 
bilgi kullanıcılarına (muhasebe bilgisine ihtiyaç duyan taraflar) raporlar halinde sunulması süreci olarak tanımlanabilir (Ertaş 2010, s.10). Muhasebe kavramının tanımına bakıldığında muhasebe süreci sonunda elde edilen bilgilere bakarak kamuoyunun mali nitelik taşıyan faaliyetlerine yön verdiği görülmektedir. Bu durum muhasebe mesleğinin sosyal-ekonomik açıdan ayrı değerlere ve öneme sahip olduğunu da göstermektedir. Muhasebe mesleği; bilgi ve yeterliliğin yanında ahlaki ve etik değerlere sahip olmayı da gerektiren bir meslektir. Ülkelerin ekonomilerini oluşturan tüm özel yada kamu işletmelerinin muhasebe faaliyetlerinin sürdürülmesi yanında bu işletmelerin ilgili yasalar, mevzuat ve standartlara göre denetlenmesi işlevlerini de tarafsız bir şekilde yürütülmesini sağlayan bir meslektir. Söz konusu durumlar mesleğin tercih edilme seviyesini ve saygınlığını da artırmaktadır (Tepeli ve Kayihan 2015).

Muhasebe mesleği, insanların sahip oldukları ekonomik varlıkları kontrol etmek ve kendilerine faydalı olacak şekilde artırmak düşüncesiyle ortaya çıkmıştır. Muhasebe mesleği çözüm aradığı problemler açısından çok disiplinli bir meslek olarak tanımlanmaktadır (Albez ve Binici 2012). Türkiye’de muhasebe mesleğini düzenleyen kanun 3568 Sayılı Serbest Muhasebeci Mali Müşavirler ve Yeminli Mali Müşavirlik Kanunu'dur. Bu Kanun’un amaçlarına bakıldığında işletme faaliyetlerinin ve işlemlerinin sağlıklı ve güvenilir şekilde yürütülmesinin sağlanması, faaliyet sonuçlarının ise ilgili mevzuatlar çerçevesinde denetlenmesinin ve değerlendirilmesinin yapıldıktan sonra tarafsız olarak sunulmasının gerçekleştirilmesi olduğu görülmektedir. İlgili Kanunda serbest muhasebeci ve mali müşavirlik ile yeminli mali müşavirlik hakkında usul ve esaslar verilmektedir.

Bütün faaliyet alanlarında olduğu gibi muhasebe sektöründe de rekabet edebilmek için nitelikli insan yetiştirmek ve muhasebe mesleği kazandırma ile bu kazanımların etkinliğini sürekli kılma çabaları oldukça önem kazanmaktadır. Değişen ve gelişen teknoloji ile birlikte büyüyen ekonominin beraberinde getirdiği bu rekabetçi ortama mesleki olarak uyum sağlayabilmek ancak iyi bir muhasebe eğitimi almakla mümkün olabilecektir. Muhasebe eğitiminde asıl amaç finansal bilgileri kullanmak zorunda olan taraflara doğru ve güvenilir bilgilerin ne şekilde ulaştırılması gerektiğini göstermek ve verilen eğitimin uygulamalarına yönlendirmelerin yapılmasıdır (Cengiz ve Yayla 2005).

Türkiye'de ilk muhasebe eğitimi 1868 yılında kurulmuş olan "Mekteb-i Mülkiyeyi Şahane" okulunda başlamıştır. Zamanla muhasebe eğitimi veren okulların sayısı artmıştır. Muhasebe alanında meslek mensubu olabilmek için muhasebe eğitimi verilen bir eğitim kurumundan diploma alma zorunluluğu bulunmaktadır (Dinç 2008).

\section{LITERATÜR TARAMASI}

İlgili literatür incelendiğinde, muhasebe eğitimi alan öğrencilerin muhasebe alanında çalışma niyetlerini etkileyen faktörleri ele alan sınırlı sayıda çalışma olduğu görülmektedir. Dinç (2008) Kocaeli Üniversitesindeki 10 MYO'da muhasebe eğitimi alan öğrenciler üzerinde yaptığı çalışmada; öğrencilerin meslek seçimine etkili olabilecek 7 faktör tespit 
etmiştir. Bunlardan yüksek kazanç ve sorumluluk beklentisi, kariyer beklentisi, mesleki bilgi ve beceri, mesleki tecrübe ve sosyal statü beklentisi faktörlerinin muhasebe mesleğinin seçiminde etkili olduğu, aile çevresi ve eğitim çevresi faktörlerinin etkili olmadığını ortaya koymuştur. Ayrıca araştırmacı, son sınıf öğrencilerinin çoğunluğunun muhasebe alanında kariyer yapmayı düşündüklerini de belirlemiştir. Çelenk vd. (2010) Marmara Üniversitesi’nde lisans ve lisansüstü düzeyde muhasebe eğitimi alan öğrenciler üzerinde yaptıkları çalışmalarında; öğrencilerin muhasebe alanında çalışma isteklerine muhasebe alanında aldıkları ilk muhasebe dersleri, dersleri veren alan hocaları, muhasebe alanında iş bulma imkânları ve muhasebe alanının prestijli olması faktörlerinin etki ettiğini tespit etmişlerdir. $\mathrm{Bu}$ faktörlerden en büyük etkiyi muhasebe alanında iş bulma imkânlarının olması olduğunu belirlemişlerdir. Diğer taraftan muhasebe alanında tanıdık biri olması boyutu öğrencilerin muhasebe alanına yönelmesinde yeterince etkili olmadığı sonucuna da ulaşmışlardır. Gençtürk vd. (2008) muhasebe eğitimi alan öğrencilerin mesleki kariyer yapmada muhasebefinans eğitiminin önemli rol oynadığını belirlemişlerdir. Hacırüstemoğlu'da (2008) günümüzde teknoloji alanındaki gelişmelerin muhasebe mesleğini de etkilediğini belirterek muhasebe eğitiminin bu gelişmelere paralel olarak geliştirilmesi gerektiğini ileri sürmüştür. Araştırmacı öğrencilerin muhasebe alanında en az üç mesleki kariyer belirlemeleri gerektiğini ve öğrencilerin yeteneklerini, ilgi alanlarını ve değerlerini bu kriterlere göre belirleyip analiz etmelerini tavsiye etmiştir.

Tepeli ve Kayıhan (2010) öğrencilerin muhasebe mesleğini tercih etmelerinde; temel faktör, kazanç faktörü, çevre faktörü, kariyer beklentisi faktörü ve fayda-maliyet faktörlerinin etkili olduğunu ortaya koymuşlar ve bunlardan fayda-maliyet boyutunun en önemli faktör, çevre boyutunun da en az öneme sahip olan faktör olduğu sonucuna ulaşmışlardır. Çalışmanın genel sonucuna göre öğrencilerin muhasebe mesleğine ilgi göstermediklerini tespit etmişlerdir. Bunu aksine Terim ve Öztürk (2009), Celal Bayar Üniversitesi Göndes MYO’da, Albez ve Binici'de (2012) Atatürk Üniversitesinde muhasebe eğitimi alan öğrenciler üzerinde yaptıkları çalışmalarında, öğrencilerin mezuniyet sonrasında muhasebe mesleğine olumlu baktıklarını tespit etmişlerdir. Tekşen vd.'de (2009) muhasebe eğitimi alan öğrencilerin mezun olduktan sonra muhasebe alanında çalışmayı düşündüklerini ama serbest muhasebe bürosu açmayı düşünmedikleri sonucunu ortaya koymuşlardır.

Küçük (2011) Erciyes Üniversitesi İktisadi ve İdari Bilimler Fakültesinde muhasebe eğitimi alan öğrencilerin mali müşavir olma niyetine etki eden beş faktör ortaya koymuştur. Bunlar: serbest çalışma imkânı sunması, resmi bir unvan sağlaması, prestijli firmalarda çalışma imkânı sunması, yaşam boyu gelir potansiyelinin yüksek olması ve kariyer potansiyelinin yüksek olmasıdır. Ömürbek ve Usul (2008) muhasebe meslek elemanlar1 üzerinde yaptıkları çalışmalarında muhasebe mesleğinin seçiminde sırasıyla kişinin meslek ile ilgili düşünceleri, mesleğin yapısından kaynaklanan etkenler ve çevresel etkenlerin etkili olduğu sonucuna ulaşmışlardır. Gökgöz ve Zeytin (2012) Yalova ve Bilecik illerinde çalışan muhasebe meslek mensuplarının, muhasebe mesleğini seçme nedenleri üzerinde yaptıkları 
çalışmalarında; muhasebe meslek mensuplarının bu mesleği seçmesine etkili olan altı faktör ortaya koymuşlar ve bunlardan mesleğin saygın bir statü sunması, mesleğin masa baş1 işlerden olması, mesleğin gelecekte de önemini koruyacağı düşüncesi, bir kentli mesleği olması ve meslek gelirinin iyi olması açıklayıcılığ yüksek olan faktörler olarak belirlenmiştir. Araştırmacılar, mesleğin saygın bir sosyal statü sunması, masa başı işlerden olması ve gelecekte de önemini koruması boyutlarının bu meslek seçiminde en etkili faktörler olduğunu tespit etmişlerdir.

Uluslararası yazında da ilgili konuyu ele alan çalışmalar mevcuttur. Danziger ve Eden (2006) İsrail'de muhasebe eğitimi alan ilk ve son sınıf öğrencilerinin kariyer planlarını karşılaştırdıkları çalışmalarında, öğrencilerin muhasebe alanında kariyer yapma düşüncelerinin son sınıfta belirginleşmeye başladığı ve ilk yıllara göre muhasebe alanında çalışmayı daha az düşündüklerini ortaya koymuşlardır. Bryne ve Willis (2005) İrlanda'da muhasebe eğitimi alan öğrenciler üzerinde yaptığı çalışmada, öğrencilerin muhasebe mesleğini sıkıcı ve katı kurallara bağlı bir meslek olarak algıladıklarını ortaya koymuşlardır. Öğrencilerin bu algılamalarının ise okul şartları, sosyal çevre ve öğretim elemanları tarafından etkilendiği tespit edilmiştir. Diğer taraftan öğrencilerin muhasebe mesleğini toplum içinde saygın fakat diğer mesleklere göre daha düşük seviyede bulduklarını belirlemişlerdir. Felton vd. (1994; aktaran Dinç 2008)) Kanada'da muhasebe eğitimi alan öğrencilerin muhasebe mesleğini seçmede, yüksek kazanç, uzun vadede yüksek kazanç, mesleki itibar, meslek içi ödül ve muhasebe eğitimi faktörlerinin etki ettiğini ortaya koymuşlardır. Auyeung ve Sands (1997) Avustralya, Hong Kong ve Tayvan'da muhasebe eğitimi alan öğrencilerin kariyer seçimlerine etki eden faktörler üzerinde yaptıkları çalışmalarında; Hong Kong ve Tavvan'da eğitim alan öğrencilerin muhasebe alanında kariyer yapma isteklerinde aile etkisi, arkadaş etkisi, öğretim elemanlarının etkisi ve muhasebe alanındaki çalışanların, Avusturyalı öğrencilerin de muhasebe alanına uygun yeteneklerinin etkisi boyutunun etkili olduğunu tespit etmişlerdir. Ahmed vd. (1997) Yeni Zelenda'da muhasebe eğitimi alan öğrencilerin muhasebe alanında kariyer yapmasını etkileyen faktörleri inceledikleri çalışmalarında; temel faktörler, diğer faktörler ve lise muhasebesinin etkisi boyutlarının öğrencilerin kariyer yapmasında etkili olmadığını, diğer taraftan finansal ve işle ilgili faktörlerin öğrencilerin muhasebe alanında kariyer yapmasında önemli bir etki yaptı̆̆ını ortaya koymuşlardır. Nelson vd (2008) Amerika'da muhasebe eğitimi alan öğrencilerin mezuniyet sonrası muhasebe alanında çalışma kararlarına iş imkânlarının giderek etki ettiğini ortaya koymuştur. Ahmadi vd. (1995) ise Amerika'da muhasebeciler üzerinde yaptıkları çalışmalarında, kadınların muhasebe mesleği seçiminde iş esnekliği ve çalışma programının etkili olduğunu, erkeklerin ise ailevi sorumlulukların faktörünün etkili olduğunu ortaya koymuşlardır.

Hurt (2010) muhasebe eğitimi alan öğrencilerin muhasebe alanında çalışma isteklerinin artması için bazı öneriler getirmiştir. İlk muhasebe derslerine kariyer planlama ve değerlendirme uzmanı ile muhasebe alanındaki uzman yöneticiler de davet edilerek öğrencilere muhasebe alanı ile ilgili daha detaylı bilgiler verilmesi gerektiğini, diğer taraftan 
öğrencilerin de muhasebe alanı ile ilgili toplantı ve bu tür etkinliklere katılmaları gerektiğini belirtmiştir. Eğitimin son yllında her bir öğrenci için oluşturulacak ön kariyer planının, öğrencilerin gelecekteki planlarına rehberlik edeceğini ve üniversite eğitimi boyunca mesleki firsatlar için temel oluşturacağını ileri sürmüştür.

\section{ARAŞTIRMANIN YÖNTEMI}

\section{1. Ölçüm Aracı}

Araştırmada ilk olarak muhasebe eğitimi ve kariyer kavramı ile ilgili literatür taraması yapılmış ve Duman vd. (2006) ile Pehlivan (2008) tarafından turizm eğitimi öğrencileri üzerinde kullanılan ölçek incelemeye alınmıştır. Yapılan incelemeler sonucu ölçekte yer alan ifadelerin muhasebe eğitimi alan öğrencilere uyumluluğu irdelenmiş ve bazı uzman öğretim üyeleri ile muhasebe alanında üst düzey mali müşavirlerin de görüşleri alınarak bazı maddeler ölçekten çıkarılmış, geri kalan maddelerin de yapısı değiştirilmiştir. Yapplan bu değişikler sonucu ölçek üç bölümden oluşturulmuştur. İlk bölümde muhasebe öğrencilerinin muhasebe alanına yönelik tutumlarını ölçmeye yönelik 35 ifade, ikinci bölümde muhasebe öğrencilerinin sektörde çalışma niyetlerini belirlemeye yönelik 10 ifade ve üçüncü bölümde öğrencilerin demografik özelliklerine ilişkin 7 soru bulunmaktadır. Öğrencilerin muhasebe alanına yönelik tutumları ve muhasebe alanında çalışma niyetlerinin belirlenmesine yönelik oluşturulan ifadeler toplam dereceleme ölçeği (1: Kesinlikle katılmıyorum,... 5: Kesinlikle katılıyorum) ile demografik özelliklerine yönelik ifadelerin bir kısmı açık uçlu, bir kısmı da kapalı uçlu olarak sorulmuştur.

\subsection{Araştırma Evreni ve Örneklemi}

$\mathrm{Bu}$ çalışmanın evrenini Süleyman Demirel Üniversitesi Yalvaç Büyükkutlu Uygulamalı Bilimler Yüksekokulu, Isparta Meslek Yüksekokulu, Gönen Meslek Yüksekokulu ve Eğirdir Meslek Yüksekokulunda ön lisans ve lisans düzeyinde Muhasebe eğitimi almakta olan öğrenciler oluşturmaktadır. Bu okulların tercih edilme sebebi, hedef kitle içinde yer alan bireylere daha kolay ulaşılabilir olmasıdır. Bu okullarda muhasebe eğitimi almakta olan öğrenci sayısı 2016-2017 eğitim öğretim yılı itibarı ile 1821'dir. Evrenin tamamına ulaşılmasının mümkün olmaması sebebiyle, örneklem alma yoluna gidilmiş, tesadüfi olmayan yöntemlerden kolayda örnekleme yöntemi uygulanmıştır. Dağıtılan 1500 anketten 1115 tanesi geri dönmüştür. Geri dönen anketlerden 155 tanesi yeterli veri ve anlamlılı̆̆a sahip olmadığı ve öğrencilerin bilinçsizce doldurduğu tespit edildiği için, değerlendirmeye alınmamıştır. Geriye kalan 960 anket ise değerlendirmeye alınmıştır.

\subsection{Verilerin Analizi}

Çalışmaya katılan öğrencilerin vermiş oldukları cevaplar doğrultusunda elde edilen veriler sosyal bilimler için geliştirilmiş olan bir istatistik paket programına girilmiştir. İstatistiksel olarak veriler tanımlayıcı ve çıkarımsal istatistik kapsamında ele alınmıştır. Çalışmada öncelikle çalışanların demografik özelliklerinin belirlendiği frekans dağılımları 
yapılmış ve sonrasında verilerin güvenilirliği (Cronbach Alpha) test edilmiştir. Değişkenleri daha geçerli ve güvenli bir biçimde belirlemek amacıyla, muhasebe alanına yönelik tutumları ile ilgili ifadelere faktör analizi uygulanmıştır. Sonrasında araştırmanın hipotezleri test edilmiştir. Bu amaçla t testi ve tek yönlü varyans analizlerinden yararlanılmıştır.

\section{BULGULAR}

Çalışmaya katılan öğrencilerin demografik özelliklerini belirlemeye yönelik cinsiyet, yaş, öğretim türü, mezun olunan lise, muhasebe bölümünün isteğe bağlı olarak seçimi ve muhasebe bölümünün ilk tercih olması gibi sorular yöneltilmiştir. Tanımlayıcı istatistik kapsamında elde edilen bulgular Tablo 1'de gösterilmiştir.

Tablo 1. Öğrencilerin Demografik Özellikleri

\begin{tabular}{lcc|lcc}
\hline Cinsiyet & $\mathbf{N}$ & $\mathbf{\%}$ & Öğretim Türü & $\mathbf{N}$ & $\mathbf{\%}$ \\
\hline Erkek & 405 & 43 & Normal Öğretim & 615 & 65,4 \\
Kadın & 536 & 57 & İkinci Öğretim & 325 & 34,6 \\
Toplam & 941 & 100 & Toplam & 940 & 10 \\
\hline Üniversite Sınavında İlk & $\mathbf{N}$ & $\mathbf{\%}$ & Muhasebe Bölümünü İsteyerek & $\mathbf{N}$ & $\mathbf{\%}$ \\
Tercih Mi? & & & Mi Seçti? & & \\
\hline Evet & 474 & 50,3 & Evet & 524 & 58,8 \\
Hayır & 469 & 49,7 & Hayır & 367 & 41,2 \\
Toplam & 943 & 100 & Toplam & $\mathbf{N}$ & $\mathbf{\%}$ \\
\hline Yaş & $\mathbf{N}$ & $\mathbf{\%}$ & Mezun Olunan Lise & 471 & 50 \\
\hline 20 yaş altı & 205 & 21,9 & Ticaret Lisesi & 218 & 23,1 \\
$20-22$ yaş & 634 & 67,7 & Düz Lise & 253 & 26,9 \\
22 yaş üstü & 97 & 10,4 & Diğer & 942 & 100 \\
Toplam & 936 & 100 & Toplam & & \\
\hline Öğrenim Gördüğg̈ü Okul & $\mathbf{N}$ & $\mathbf{\%}$ & & & \\
\hline Önlisans & 422 & 44 & & & \\
Lisans & 538 & 56 & & & \\
Toplam & 960 & 100 & & & \\
\hline
\end{tabular}

Tablo 1 incelendiğinde, çalışmaya katılan öğrencilerin çoğunluğunu (\% 57) kızlar ve 20-22 yaş grubu oluşturduğu görülmektedir. \% 56's1 lisans, \% 44 önlisans eğitimi almakta olan öğrencilerin \% 65,4'ü normal öğretim, \% 34,6's1 ikinci öğretimde okumaktadırlar. Araştırmaya katılan öğrencilerin yarısı ticaret lisesi, diğer yarısı diğer liselerden (Düz lise, kız meslek lisesi vb.) mezun olmuştur. Öğrencilerin \% 58,8'i muhasebe bölümünü isteyerek tercih ettiği ve \% 50,3’ü ise il tercihi olduğunu belirtmişlerdir.

Öğrencilerin muhasebe sektörüne yönelik tutumlarına ait ifadelerin boyutlu yapısını tespit etmek amacıyla açıklayıcı faktör analizi uygulanmış ve analiz sonuçları Tablo 2'de verilmiştir. 
Tablo 2. Öğrencilerin Muhasebe Sektörüne Yönelik Tutumlarına Ait Faktör Analiz Sonuçları

\begin{tabular}{|c|c|c|c|c|c|}
\hline Boyutlar & 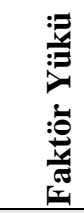 & 胥 & 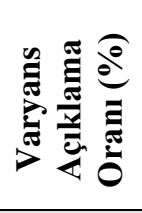 & فే & 喜 \\
\hline FAKTÖR 1: ÜCRET ve TERFİ & & 3,25 & 11,10 & 3,59 & ,691 \\
\hline Muhasebe alanında birçok işin ücreti çok düşüktür & 697 & & & & \\
\hline Sektör dışındaki ek gelirler (prim, ikramiye vb.) yetersizdir & ,695 & & & & \\
\hline Sektörde terfi imkânları kısıtlıdır &, 585 & & & & \\
\hline Bu sektörde çok para kazanabileceğimi düşünmüyorum &, 573 & & & & \\
\hline Sektörde tanıdığı (torpili) olmayanın terfi etmesi zordur &, 565 & & & & \\
\hline Daha önceki mezunlar sektörde iyi pozisyonlarda değiller &, 526 & & & & \\
\hline FAKTÖR 2: KİŞİ-SEKTÖR UYUMU & & 3,36 & 10,80 & 2,74 & ,701 \\
\hline Kişiliğim Muhasebe alanında çalışmaya uygundur & ,787 & & & & \\
\hline Muhasebe alanındaki işlerde bilgi ve becerilerimi kullanabilirim & ,778 & & & & \\
\hline Muhasebe alanında çalışmayı eğlenceli buluyorum & 624 & & & & \\
\hline Kısa sürede sektörde iyi noktalara geleceğimi düşünüyorum &, 560 & & & & \\
\hline Tempolu iş ortamını severim &, 540 & & & & \\
\hline FAKTÖR 3: YÖNETİCILER & & 3,35 & 8,39 & 1,58 & ,672 \\
\hline Yöneticiler işlerini daha iyi yapabilmek için astlarına yetki vermektedirler & ,801 & & & & \\
\hline Yöneticiler çalışanların önerilerini değerlendirirler & ,753 & & & & \\
\hline Yöneticiler gerektiğinde çalışanların mesleki eğitim almasını sağlarlar & ,704 & & & & \\
\hline FAKTÖR 4: İŞ-ÖZEL HAYAT UYUMU & & 4,30 & 8,05 & 1,42 & ,796 \\
\hline Hafta sonu tatili benim için çok önemlidir & ,870 & & & & \\
\hline Özel hayatım benim için çok önemlidir & ,858 & & & & \\
\hline FAKTÖR 5:SEKTÖR ÇALIŞANLARI & & 2,68 & 7,23 & 1,16 & ,518 \\
\hline Muhasebe alanında çalışanlarında ekip ruhu gelişmemiştir & ,722 & & & & \\
\hline Muhasebe alanında çalışanların genelde eğitim seviyesi düşüktür & ,651 & & & & \\
\hline Sektördeki yöneticilerin birçoğu muhasebe eğitimi almamışlardır & ,641 & & & & \\
\hline FAKTÖR 6: ÇALIŞMA KOŞULLARI & & 3,45 & 7,09 & 1,06 & ,558 \\
\hline Muhasebe alanında çalışma saatleri çok uzundur & ,748 & & & & \\
\hline Muhasebe alanında çalışma saatleri düzensizdir & ,718 & & & & \\
\hline Muhasebe alanındaki çalışma ortamı streslidir &, 571 & & & & \\
\hline
\end{tabular}

İlk olarak, verilerin faktör analizi için uygun olup olmadığını test etmek için KMO (Kaiser_Meyer_Olkin) analizinden faydalanılmış ve oran 0,776 bulunmuştur. Bu oran örneklem sayısının yeterliliğini göstermektedir. Faktör analizinin ön şartlarından olan değişkenler arasındaki ilişkinin varlığı Bartlett Küresellik Testi sonucunda gösterilmiştir ( $\mathrm{p}=$ 0,000). Ankette öğrencilerin muhasebe sektörüne tutumlarını ölçmek için kullanılan 35 önerme faktör analizine dâhil edilmiştir. Eşkökenliliği (communality) 0,5'in altında olan 13 ifadenin elenmesi sonucu toplam varyansın \% 52,67'sini açıklayan ve özdeğeri 1'in üstünde olan altı faktör elde edilmiştir.

Birinci faktör toplam varyansın \% 11,10’unu açıklamakta olup “Ücret ve Terfi” olarak isimlendirilmiş ve altı ifadeden oluşmuştur. Bu faktörü oluşturan ifadeler; muhasebe alanında ücretlerin düşük olması, ek gelirlerinin olmaması, terfi imkânlarının kısıtlı olması ve daha 
önceki mezunların iyi yerde olmaması ifadeleridir. İkinci faktör toplam varyansın \% 10,80’ini açıklamakta olup "Kişi-sektör uyumu” olarak isimlendirilmiş ve beş ifadeden oluşmuştur. Bu faktör ise, kişiliğin muhasebe alanında çalışmaya uygun olması, muhasebe alanında bilgi ve becerilerin kullanılabilmesi, sektörde çalışmanın eğlenceli olması, iyi bir kariyer yapabilme inancı ve yoğun iş temposuna alışık olması ifadelerinden oluşmaktadır. "Yöneticiler" olarak isimlendirilen üçüncü faktör toplam varyansın \% 8,39'unu açılamakta olup üç ifadeden oluşmuştur. $\mathrm{Bu}$ faktörü oluşturan ifadeler, yöneticilerin işlerini daha iyi yapabilmesi için astlarına yetki vermesi, çalışanların önerilerini dikkate alması ve çalışanların mesleki eğitim aldırması ifadeleridir. Dördüncü faktör "İş-özel hayat uyumu" olarak isimlendirilmiş ve iki ifadeden oluşmuştur. Bu faktör toplam varyansın \% 8,05'ini açıklamaktadır. Hafta sonu tatili ve özel hayatın önemli olması ifadeleri bu faktörü oluşturan önermelerdir. Beşinci faktör "Sektör çalışanları" olarak isimlendirilmiş olup toplam varyansın \% 7,23’ünü açıklamaktadır. Bu faktör de üç değişkenden oluşmaktadır. Bu ifadeler, muhasebe alanında çalışanların ekip ruhunun gelişmemiş olması, genelde çalışanların eğitim seviyelerinin düşük olması ve çoğunun muhasebe eğitimi almamış olması önermeleridir. Altıncı faktör toplam varyansın \% 7,09’unu açıklamakta olup “Çalışma koşulları” olarak isimlendirilmiş ve üç ifadeden oluşmuştur. $\mathrm{Bu}$ ifadeler ise muhasebe alanında çalışma saatlerinin uzun olması, düzensiz olması ve çalışma ortamının stresli olması ifadelerinden oluşmaktadır.

Çalışmada elde edilen faktörlere güvenilirlik analizi uygulanmış ve her faktör için genel güvenilirlik değeri (Cronbach Alpha Katsayısı) bulunmuştur ( ücret ve terfi için 0,691 kişi-sektör uyumu için 0,701 - yöneticiler için 0,672 - iş-özel hayat uyumu için 0,796 sektör çalışanları için 0,518 ve çalışma koşulları için 0,558). Her ne kadar sektör çalışanları ve çalışma koşulları boyutlarının güvenilirlik düzeyleri düşük çıksa da, bulunan değerler kabul edilebilir sınırlar içerisindedir (Kalaycı, 2010: 405).

Son olarak elde edilen her bir faktörün ortalamaları alınmıştır. Ücret ve terfi faktörünün ortalaması 3,25; kişi-sektör uyumu faktörünün ortalaması 3,36; yöneticiler faktörünün ortalaması 3,35; iş-özel hayat uyumu faktörünün ortalaması 4,30; sektör çalışanları faktörünün ortalaması 2,68 ve çalışma koşulları faktörünün ortalaması 3,45 olarak tespit edilmiştir. Bu verilere göre, ele alınan örneklem kapsamında, iş-özel hayat uyumu boyutunun ortalaması en yüksek iken; ücret ve terfi boyutu ise en düşük orana sahip olduğunu söylemek mümkündür.

Çalışmada muhasebe sektöründe çalışma niyetine yönelik yedi ifadenin boyutlu yapısını tespit etmek için yapılan açıklayıcı faktör analiz sonucuna göre; 5 ifadeden oluşan tek bir faktör boyutu elde edilmiştir (Tablo 3). 
Tablo 3. Öğrencilerin Muhasebe Alanında Kalma Niyetlerine Ait Faktör Analiz Sonuçları

\begin{tabular}{|c|c|c|c|c|c|}
\hline Boyutlar & 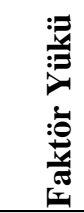 & 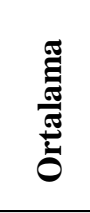 & 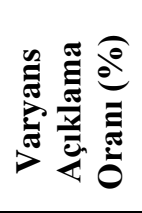 & Oे & 喜 \\
\hline FAKTÖR 1: Sektörde Kalma Niyeti* & & 3,34 & 58,30 & 2,91 & ,819 \\
\hline Bu sektörde uzun yıllar çalışamam & 824 & & & & \\
\hline Mezun olunca muhasebe alanında çalışacağımı sanmıyorum & ,816 & & & & \\
\hline Bu mesleği seçmem benim için bir hatayd 1 & ,769 & & & & \\
\hline Muhasebe alanında kariyer yapmamın bana kazandıracağı bir şey yok & ,702 & & & & \\
\hline Mezun olunca ne iş yapacağımı bilmiyorum & ,697 & & & & \\
\hline
\end{tabular}

Tablo 3'te görüldüğü gibi elde edilen boyut toplam varyansın \% 58'ini açıklamakta olup “sektörde kalma niyeti” olarak isimlendirilmiştir.

\section{Araştırmanın Hipotez Testleri}

Hipotez 1: Öğrencilerin muhasebe alanına yönelik tutumları cinsiyete göre farklılaşmaktadır.

Öğrencilerin cinsiyetleri ile muhasebe alanına yönelik tutumlarına ait boyutlar arasında anlamlı bir farklılık olup olmadığını karşılaştırmak amacıyla t-testi gerçekleştirilmiş ve sonuçlar Tablo 4'te verilmiştir.

Tablo 4. Öğrencilerin Muhasebe Alanına Yönelik Tutumlarının Cinsiyete Göre Farklılı̆̆

\begin{tabular}{|c|c|c|c|c|c|c|}
\hline \multirow[b]{2}{*}{ Boyutlar } & \multicolumn{2}{|c|}{ Erkek } & \multicolumn{2}{|c|}{$\overline{K_{1 Z}}$} & \multirow[b]{2}{*}{$\mathrm{t}$} & \multirow[b]{2}{*}{$\mathrm{p}$} \\
\hline & Ort. & S.S & Ort. & S.S & & \\
\hline Ücret ve Terfi & 3,27 & ,752 & 3,25 & ,732 & ,427 & 670 \\
\hline Kişi-Sektör Uyumu & 3,37 & ,848 & 3,37 & ,763 &,- 084 & ,933 \\
\hline Yöneticiler & 3,38 & ,881 & 3,31 & ,841 & 1,189 & ,235 \\
\hline İş-Özel Hayat Uyumu & 4,28 & 1,068 & 4,33 & 1,009 &,- 666 &, 505 \\
\hline Sektör Çalışanları & 2,67 & 908 & 2,68 & 819 &,- 145 & ,884 \\
\hline Çalışma Koşulları & 3,40 & ,903 & 3,49 & ,873 & $-1,582$ & ,114 \\
\hline
\end{tabular}

Tablo 4 incelendiğinde tüm boyutlarda istatistiki açıdan anlamlı farklılık olmadığı görülmektedir. Dolayısıyla H1 hipotezi reddedilmiştir.

Hipotez 2: Öğrencilerin muhasebe alanına yönelik tutumları öğretim türlerine göre farklılaşmaktadır. 
Öğrencilerin öğrenim gördükleri öğretim türü ile muhasebe alanına yönelik tutumlarına ait boyutlar arasında anlamlı bir farklılık olup olmadığını karşılaştırmak amacıyla t-testi gerçekleştirilmiş ve sonuçlar Tablo 5 'te verilmiştir.

Tablo 5. Öğrencilerin Muhasebe Alanına Yönelik Tutumlarının Öğretim Türüne Göre Farklılığı

Tablo 5 incelendiğinde ücret ve terfi $(\mathrm{p}=, 543>0,05)$, kişi-sektör uyumu $(\mathrm{p}=, 135>0,05)$, iş-özel hayat uyumu $(\mathrm{p}=, 266>0,05)$, sektör çalışanları $(\mathrm{p}=, 533>0,05)$ ve çalışma koşulları $(\mathrm{p}=, 708>0,05)$ boyutlarının öğretim türü değişkenine göre anlamlı farklılık göstermediği, diğer taraftan yöneticiler $(\mathrm{p}=, 033<0,05$ boyutunun anlamlı farklılık gösterdiği görülmektedir. $\mathrm{Bu}$ sonuca göre yöneticiler boyutunda ikinci öğretim öğrencilerinin muhasebe alanına yönelik tutumlarının birinci öğretim öğrencilerine göre daha yüksek olduğu söylenebilir. Sonuç olarak H2 hipotezi kısmen kabul edilmiştir.

Hipotez 3: Öğrencilerin muhasebe alanına yönelik tutumları mezun oldukları liseye göre farklılaşmaktadır.

Öğrencilerin mezun oldukları lise ile muhasebe alanına yönelik tutumlarına ait boyutlar arasında anlamlı bir farklılık olup olmadığını karşılaştırmak amacıyla t-testi gerçekleştirilmiş ve sonuçlar Tablo 6'da verilmiştir.

Tablo 6. Öğrencilerin Muhasebe Alanına Yönelik Tutumlarının Mezun Oldukları Liseye Göre Farklılığı

\begin{tabular}{|c|c|c|c|c|c|c|}
\hline \multirow[b]{2}{*}{ Boyutlar } & \multicolumn{2}{|c|}{ Ticaret Lisesi } & \multicolumn{2}{|c|}{ Diğer Liseler } & \multirow[b]{2}{*}{$\mathrm{t}$} & \multirow[b]{2}{*}{$\mathrm{p}$} \\
\hline & Ort. & S.S & Ort. & S.S & & \\
\hline Ücret ve Terfi & 3,27 & & 3,24 & & 663 & ,507 \\
\hline Kişi-Sektör Uyumu & 3,46 & & 3,27 & & 3,658 &, $000 * *$ \\
\hline Yöneticiler & 3,36 & & 3,33 & & ,458 & 647 \\
\hline İş-Özel Hayat Uyumu & 4,32 & & 4,29 & & ,390 & ,697 \\
\hline Sektör Çalışanları & 2,65 & & 2,70 & &,- 869 & 385 \\
\hline Çalışma Koşulları & 3,51 & & 3,39 & & 2,135 & ,033* \\
\hline
\end{tabular}


Tablo 6 incelendiğinde ücret ve terfi $(p=, 507>0,05)$, yöneticiler $(p=, 647>0,05)$, iş-özel hayat uyumu $(p=, 697>0,05)$ ve sektör çalışanları $(p=, 385>0,05)$ boyutlarının mezun olunan liseye göre anlamlı farklılık göstermediği, diğer taraftan kişi-sektör uyumu $(p=, 000<0,05)$ ve çalışma koşulları $(p=, 033>0,05)$ boyutlarının anlamlı farklılık gösterdiği görülmektedir. Buna göre anlamlı farklılık tespit edilen boyutlarda Ticaret Lisesi mezunu öğrencilerinin muhasebe alanına yönelik tutumlarının diğer liselerden mezun olan öğrencilere göre daha yüksek olduğu söylenebilir. Sonuç olarak H3 hipotezi kısmen kabul edilmiştir.

Hipotez 4: Öğrencilerin muhasebe alanına yönelik tutumları öğrenim gördükleri okul türüne göre farklılaşmaktadır.

Öğrencilerin öğrenim gördükleri okul türü ile muhasebe alanına yönelik tutumlarına ait boyutlar arasında anlamlı bir farklılık olup olmadığını karşılaştırmak amacıyla t-testi gerçekleştirilmiş ve sonuçlar Tablo 7'de verilmiştir.

Tablo 7. Öğrencilerin Muhasebe Alanına Yönelik Tutumlarının Okul Türüne Göre Farklılı̆̆

\begin{tabular}{|c|c|c|c|c|c|c|}
\hline \multirow[b]{2}{*}{ Boyutlar } & \multicolumn{2}{|c|}{ Önlisans } & \multicolumn{2}{|c|}{ Lisans } & \multirow[b]{2}{*}{$\mathrm{t}$} & \multirow[b]{2}{*}{$\mathrm{p}$} \\
\hline & Ort. & S.S & Ort. & S.S & & \\
\hline Ücret ve Terfi & 3,19 & 787 & 3,30 & ,710 & $-2,142$ &, $032 *$ \\
\hline Kişi-Sektör Uyumu & 3,26 & 830 & 3,45 & ,775 & $-3,714$ &, $000^{* *}$ \\
\hline Yöneticiler & 3,29 & ,945 & 3,39 & ,802 & $-1,770$ & ,077 \\
\hline İş-Özel Hayat Uyumu & 4,16 & 1,145 & 4,41 & 924 & $-3,705$ & ,000** \\
\hline Sektör Çalışanları & 2,71 & ,919 & 2,66 & ,818 & 1,003 & ,316 \\
\hline Çalışma Koşulları & 3,33 & 927 & 3,54 & ,844 & $-3,619$ &, $000 * *$ \\
\hline
\end{tabular}

Tablo 7 incelendiğinde yöneticiler $(p=, 077>0,05)$ ve sektör çalışanları ( $p=, 316>0,05)$ boyutlarının öğrenim görülmekte olan okul türüne göre anlamlı farklılık göstermediği, diğer taraftan ücret ve terfi $(p=, 032<0,05)$, kişi-sektör uyumu $(p=, 000>0,01)$, iş-özel hayat uyumu $(p=, 000>0,01)$ ve çalışma koşulları $(p=, 000>0,01)$ boyutlarının anlamlı farklılık gösterdiği görülmektedir. Buna göre anlamlı farklılık tespit edilen tüm boyutlarda lisans öğrencilerinin muhasebe alanına yönelik tutumlarının ön-lisans öğrencilerine göre daha yüksek olduğu söylenebilir. Sonuç olarak H4 hipotezi kabul edilmiştir.

Hipotez 5: Öğrencilerin muhasebe alanına yönelik tutumları ve sektörde kalma niyetleri arasında ilişki vardır.

Öğrencilerin muhasebe alanına yönelik tutum boyutları ile sektörde kalma niyetleri arasında bir ilişkinin olup olmadığını belirlemek amacıyla korelasyon analizi gerçekleştirilmiş ve sonuçlar Tablo 8'de gösterilmiştir. 
Tablo 8. Muhasebe Alanına Yönelik Tutumları İçeren Boyutlar ile Sektörde Kalma Niyeti Arasındaki İlişkiler

\begin{tabular}{|c|c|c|c|c|c|c|c|c|}
\hline Boyutlar & & 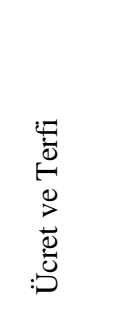 & 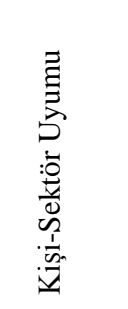 & 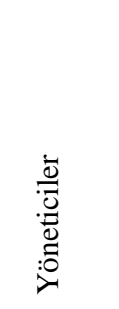 & 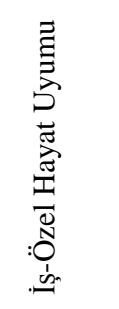 & 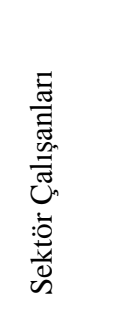 & 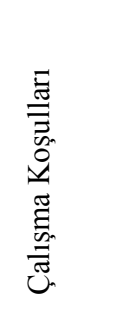 & 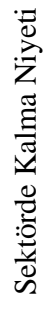 \\
\hline Ücret ve Terfi & Pearson Cor. & 1 & & & & & & \\
\hline Kişi-Sektör Uyumu & Pearson Cor. & ,030 & 1 & & & & & \\
\hline Yöneticiler & Pearson Cor. & ,043 & ,318** & 1 & & & & \\
\hline İş-Özel Hayat Uyumu & Pearson Cor. & ,267** & ,202** &, $150 * *$ & 1 & & & \\
\hline Sektör Çalışanları & Pearson Cor. &, $305^{* *}$ &,$- 076 *$ &,- 033 &,- 004 & 1 & & \\
\hline Çalışma Koşulları & Pearson Cor. & ,338** & ,137** &, $152^{* *}$ & ,345** & ,132** & 1 & \\
\hline Sektörde Kalma Niyeti & Pearson Cor & ,319** &,$- 326 * *$ &,- 048 & 039 & ,307** &, $160 * *$ & 1 \\
\hline
\end{tabular}

Tablo 8 incelendiğinde sektörde kalma niyeti ile ücret ve terfi, kişi-sektör uyumu, sektör çalışanları ve çalışma koşulları boyutları arasında anlamlı $(\mathrm{p}<, 001)$ ve pozitif yönde bir ilişkinin olduğu görülmektedir. Korelasyon tablosunda negatif yönde gözüken ilişkiler faktör boyutlarının olumsuz ifadelerden oluşmasından dolayı pozitif yönlü ilişkileri ifade etmektedir.

Hipotez 6: Öğrencilerin muhasebe alanına yönelik tutumları, sektörde kalma niyetlerine etki etmektedir.

Öğrencilerin muhasebe alanına yönelik tutum boyutlarının sektörde kalma niyetleri üzerindeki etkilerini belirlemek amaciyla çok değişkenli regresyon analizi gerçekleştirilmiş ve sonuçlar Tablo 9'da gösterilmiştir. Regresyon analizinde "sektörde kalma niyeti” değişkeni bağımsız değişken olarak kullanılmıştır.

Tablo 9. Faktör Boyutlarının Otel Tercihlerine Etkileri

\begin{tabular}{lcrc}
\hline Faktör Boyutları & $\boldsymbol{\beta}$ & $\mathbf{t}$ & $\mathbf{p}^{*}$ \\
\hline Ücret ve Terfi &, 232 & 7,314 &, $000^{*}$ \\
Kişi-Sektör Uyumu &, 342 & 11,327 &, $000^{*}$ \\
Yöneticiler &, 046 & 1,528 &, 127 \\
İş-Özel Hayat Uyumu &, 006 &, 205 &, 838 \\
Sektör Çalışanları &, 197 & 6,580 &, $000^{*}$ \\
Çalışma Koşulları &, 092 & 2,918 &, $004^{*}$ \\
\hline
\end{tabular}

${ }^{*} \mathrm{p}<0,01 \quad \mathrm{R}^{2}=0,259 \quad \mathrm{~F}=54,302 \quad \mathrm{p}=0,000 ; \quad$ Bağımlı Değişken: Sektörde Kalma Niyeti 
Tablo 9'da yer alan regresyon analizi sonuçlarına göre, bağımsız değişkenlerden ücret ve terfi, kişi-sektör uyumu, sektör çalışanları ve çalışma koşulları boyutlarının beta katsayıları da 0,01 seviyesinde anlamlı, diğer bağımsız değişkenlerden yöneticiler ile iş-özel hayat uyumu boyutlarının beta katsayıları 0,01 seviyesinde anlamsız bulunmuştur. Çıkan analiz sonuçları göre modelin bir bütün olarak anlamlı $(\mathrm{F}=54,302 ; \mathrm{p}=0,000)$ olduğunu ve bağımsız değişkenlerin sektörde kalma niyetini \% 26 oranında açıkladığı tespit edilmiştir. Tablo 9 incelendiğinde öğrencilerin muhasebe alanında çalışma niyetlerinde en etkili faktörün kişisektör uyumu $(\beta=0,342 ; \mathrm{t}=11,32 ; \mathrm{p}<0,01)$ olduğu görülmektedir. Buna göre öğrencilerin muhasebe alanında kalma niyetini etkileyen en önemli neden öğrencinin kişiliğinin muhasebe alanında çalışmaya uygun bulması konusundaki tutumu olduğu söylenebilir.

\section{SONUÇLAR}

$\mathrm{Bu}$ çalışmada önlisans ve lisans düzeyinde muhasebe eğitimi alan öğrencilerin muhasebe mesleğine yönelik tutumları ve bu tutumların muhasebe alanında çalışma niyetleri üzerindeki etkileri araştırılmıştır. Çalışmada ilk olarak öğrencilerin muhasebe alanına yönelik tutumlarını ölçmeye yönelik oluşturulan ifadelerin boyutlu yapısını belirlemek için açıklayıcı faktör analizi gerçekleştirilmiş ve öğrencilerin muhasebe mesleğine yönelik tutumlarına ilişkin ücret ve terfi, kişi-sektör uyumu, yöneticiler, iş-özel hayat uyumu, sektör çalışanları ve çalışma koşulları olmak üzere altı boyut elde edilmiştir. Elde edilen bu boyutların ortalamaları karşılaş̧ırıldığında, öğrencilerin muhasebe mesleğine yönelik tutumlarında en önemli faktörün iş-özel hayat boyutu olduğu belirlenirken, ücret ve terfi boyutunun ise en az öneme sahip faktör olduğu sonucuna ulaşılmıştır. Bu sonuç Duman vd. (2006) ve Pehlivan'nın (2008) turizm eğitimi alan öğrenciler üzerinde yaptı̆̆ çalışma sonucu ile paralellik göstermektedir. Diğer taraftan elde edilen faktör boyutlarının öğrencilerin muhasebe mesleğinde çalışma niyetlerine etkisi belirlemek amacıyla gerçekleştirilen çok değişkenli regresyon analiz sonucuna göre; öğrencilerin muhasebe alanında çalı̧̧ma niyetine en fazla kişi-sektör uyumunun etki ettiği ortaya konulmuştur. Başka bir ifadeyle öğrencilerin kendilerini muhasebe alanında çalışmaya uygun bulup bulmadığı tutumu belirleyici konumundadır. Bu sonuca göre kişiliğini, alanı ile bilgi ve becerilerini ve sahip olduğu özellikleri muhasebe alanında çalışmaya uygun bulan öğrenciler, kendi alanlarında çalışmaya daha olumlu bakmaktadırlar. Bu sonuç ta Ömürbek ve Usul'un (2008) bulguları ile örtüşmektedir.

Öğrencilerin muhasebe mesleğine yönelik tutumlarını belirleyen faktör boyutları ile öğrencilerin cinsiyetleri, öğretim türleri, mezun oldukları lise ve okul türü arasındaki farklılıkları belirlemeye yönelik gerçekleştirilen analizlere göre aşağıdaki sonuçlara ulaşılmıştır.

Öğrencilerin muhasebe mesleğine yönelik tutumlarına etki eden faktörler ile cinsiyet arasında anlamlı farklılık bulunamamıştır. 
- $\quad$ Öğrencilerin muhasebe mesleğine yönelik tutumlarına etki eden faktörlerden yönetici boyutu ile öğrencilerin öğretim türü arasında anlamlı farkl1lık bulunmuştur. $\mathrm{Bu}$ boyutta ikinci öğretim öğrencilerinin muhasebe mesleğine yönelik tutumlarının daha yüksek olduğu tespit edilmiştir

Öğrencilerin muhasebe mesleğine yönelik tutumlarına etki eden faktörlerden kişi-sektör uyumu boyutu ile öğrencilerin mezun oldukları lise arasında anlamlı farklılık bulunmuştur. Bu boyutta ticaret lisesi mezunlarının diğer lise mezunlarına göre muhasebe mesleğine yönelik tutumlarının daha yüksek olduğu belirlenmiş̦tir.

Öğrencilerin muhasebe mesleğine yönelik tutumlarına etki eden faktörlerden ücret ve terfi, kişi-sektör uyumu, iş-özel hayat uyumu ve çalışma koşulları boyutları ile öğrencilerin okul türü arasında anlamlı farklılıklar bulunmuştur. Anlamlı farklılık bulunan tüm boyutlarda lisans öğrencilerinin ön-lisans öğrencilerine göre muhasebe mesleğine yönelik tutumlarının daha yüksek olduğu ortaya konulmuştur.

$\mathrm{Bu}$ çalışma Süleyman Demirel Üniversitesi'nde muhasebe eğitimi alan öğrencilerin ele alınmış olması elde edilen sonuçların genellemesini sınırlamaktadır. İleride yapılacak çalışmalarda bu hususun dikkate alınarak, farklı üniversitelerde ve farklı bölümlerde eğitim almakta alan (İşletme, Ekonomi ve İktisat gibi) öğrenciler üzerinde çalışmaların yapılması daha genellenebilir sonuçların elde edilmesine olanak sağlayacaktır.

\section{KAYNAKLAR}

Ahmadi M.- Helms M.M. v- Nodoushani P. (1995). "A Factor-Analytic Approach Profiling Job Selection Differences of Male and Female Accountants”, Managerial Auditing Journal, 10(7),pp. 17-24.

Ahmed K.- Alam F.K. - Alam M. (1997). “An Empirical Study of Factors Affecting Accounting Students' Career Choice in New Zeland", Accounting Education: An International Journal, 6(4), pp. 325-335.

Albez A. - Bilici N. (2012). "Meslek Yüksekokulları Muhasebe Öğrencilerinin Mesleğe Bakışları: Atatürk Üniversitesi’nde Bir Araştırma”, Atatürk Üniversitesi Sosyal Bilimler Enstitüsü Dergisi, 16(3), ss. 383-398.

Auyeung P. - Sands J. (1997). "Factors Influencing Accounting Students' Career Choice: A Cross-Cultural Validation Study”, Accounting Education: An International Journal, 6(1), pp. 13-23.

Byrne M. - Willis P. (2005). "Irish Secondary Students' Perceptions of the Work of an Accountant and the Accounting Profession”, Accounting Education: An International Journal, 14(4), pp. 367-381. 
Cengiz E. - Yayla H.E. (2005). "Muhasebe Mesleğinin Tercih Edilmesinde Etkili Olan Faktörlerin Belirlenmesine Yönelik Bir Alan Çalışması: Karadeniz Teknik Üniversitesi Örneği”, Muhasebe ve Denetime Bakış Dergisi, 16(5), ss. 153-154.

Çelenk H. - Atmaca M. - Horasan E. (2010). “Marmara Üniversitesi’inde Muhasebe Eğitimi Alan Öğrencilerin Muhasebe Alanına Bakış Açılarının Değerlendirilmesine Yönelik Bir Araştırma”, Öneri Dergisi, 33(9), ss. 159-171.

Danziger N. - Eden Y. (2006). "Student Career Aspirations and Perceptions: The Case of Israeli Accounting Students”, Accounting Education: An International Journal, 15(2), pp. 113-134.

Dinç E. (2008). “Meslek Seçiminde Etkili Faktörlerin İncelenmesi: Meslek Yüksekokulu Muhasebe Programı Öğrencileri Üzerine Bir Araştırma”, Kocaeli Üniversitesi Sosyal Bilimler Enstitüsü Dergisi, 16(2), ss. 90-106.

Duman T. - Tepeci M. - Unur K. (2006). "Mersin'de Yükseköğretim ve Orta Öğretim Düzeyinde Turizm Eğitimi Almakta Olan Öğrencilerin Sektörün Çalışma Koşullarını Algılamaları ve Sektörde Çalışma İsteklerinin Karşıllaştırmalı Analizi”, Anatolia: Turizm Araştırmaları Dergisi, 17(1), ss. 51-69.

Ertaş F.Ç. (2010). Genel Muhasebe. Lisans Yayıncılık, İstanbul.

Gençtürk M. - Demir Y. - Çarıkçı O. (2008). "Meslek Yüksekokulu Öğrencilerinin Muhasebe-Finans Eğitimine Bakış Açıları ve Farkındalıkları Üzerine Bir Uygulama”, Süleyman Demirel Üniversitesi İktisadi ve İdari Bilimler Fakültesi Dergisi, 13(1), ss. 209-228.

Gökgöz A. - Zeytin M. (2012). "Muhasebe Mesleğinin Seçilmesini Etkileyen Faktörlerin İncelenmesi: Yalova ve Bilecik İlleri Örneği”. Uluslararası İktisadi ve İdari İncelemeler Dergisi, 4(8), ss. 67-85.

Hacırüstemoğlu R. (2008). "Bilgi Çağında Muhasebe Eğitimi”, Muhasebe Bilim Dünyası Dergisi 3, ss. 1-6.

Hurt B. (2010). “Teaching What Matters: A New Conception of Accounting Education”, Journal of Education for Business, 82(5), pp. 295-299.

Kalaycı, Ş. (2010). SPSS Uygulamalı Çok Değişkenli İstatistik Teknikleri. Asil Yayın Dağıtım, Ankara.

Küçük E. (2011). "Planlanmış Davranış Teorisi Çerçevesinde Mali Müşavir (SMMM) Olma Niyetinin Altında Yatan Faktörlerin Analizi”, ZKÜ Sosyal Bilimler Dergisi, 7(1), ss. 145-162. 
Nelson T.I. - Vendrzyk P.V. - Quirin J.J. - Kovar E.S. (2008). “Trends in Accounting Student Characteristics: Result From A 15-Year Longitudinal Study At FSA Schools”, Issues In Accounting Education, 23(3), pp. 373-389.

Ömürbek V. - Usul H. (2008). "Muhasebe Mesleğinin Seçilmesinde Etkin Olan Etkenlerin Faktör Analiziyle İncelenmesi”, Muhasebe ve Finansman Dergisi, 37, ss. 164-173.

Pehlivan R. (2008). "Lisans Düzeyinde Turizm Eğitimi Almakta Olan Öğrencilerin Sektör İle İlgili Tutumlarının Mezuniyet Sonrası Kariyer Seçimine Etkisi”, Adnan Menderes Üniversitesi Sosyal Bilimler Enstitüsü, Yüksek Lisans Tezi.

Tekşen Ö. - Tekin M. - Gençtürk M. (2009). "Muhasebe Eğitiminin Değerlendirilmesi: Mehmet Akif Ersoy Üniversitesine Bağlı MYO Öğrencileri Üzerine Bir Araştırma”, Muhasebe ve Finansman Dergisi, ss. 100-112.

Terim B. - Öztürk A. (2009). "Meslek Yüksekokulu Öğrencilerinin Muhasebe Eğitimine Bakış Açılarının Değerlendirilmesi: Gördes Meslek Yüksekokulunda Bir Uygulama”, Celal Bayar Üniversitesi Sosyal Bilimler Enstitüsü Dergisi, 7(2), ss. 153-168.

Tepeli Y. - Kayıhan B. (2015). "Muhasebe Eğitimi Alan Öğrencilerin Muhasebe Mesleğine Bakış Açılarının Değerlendirilmesi: Muğla Sıtkı Koçman Üniversitesi Örneği”, Yönetim ve Ekonomi Araştırmaları Dergisi, 13(3), ss. 138-156. 
